\title{
Effect of Cooling Rate on Microstructure of Ti- 6Al-4V Alloy Produced by Direct Metal Laser Sintering
}

\author{
Luis P. M. Santos ${ }^{1}$; \\ André L. Jardini \\ Giovani R. Gonçalves ${ }^{1}$; \\ Arthur A. Almeida ${ }^{1}$; \\ Hana L.F. Coelho ${ }^{1}$; \\ Marcelo J. Gomes da Silva ${ }^{1}$; \\ Hamilton F.G. Abreu; \\ Miloslav Béreš ${ }^{1 *}$; \\ 1 Federal University of Ceará. Department of Metallurgical Engineering \\ and Materials Science, Fortaleza, Ceará, Brazil \\ 2 University of Campinas. School of Chemical Engineering, Campinas, \\ São Paulo, Brazil \\ "Corresponding author's email: beresm@metalmat.ufc.br
}

\begin{abstract}
Direct metal laser sintering (DMLS) technique allows to build complex components directly from metal powder. In this work, Ti-6Al-4V samples with dimensions $10 \times 10 \times 10 \mathrm{~mm}^{3}$ were produced by the DMLS technique. Parallel and cross laser beam scanning strategies were employed. The alloy was then heat treated at $1040^{\circ} \mathrm{C}$ for $1 \mathrm{~h}$ followed by cooling in water and in furnace. Samples were characterized by optical and scanning electron microscopy in addition to X-ray diffraction (XRD). The microstructural examination revealed columnar prior $\beta$-grains in as received condition whereas $\alpha+\beta$ phases were observed after heat treatment, which was further confirmed by the XRD technique.
\end{abstract}

Index Terms-Ti-6Al-4V; Direct Metal Laser Sintering; Microstructure

\section{INTRODUCTION}

$\mathrm{D}$ URING the last few decades titanium alloys were developed for applications requiring good corrosion resistance and high specific strength. Typical employments include medical implants and aerospace components. Traditionally, these parts are fabricated by highcost machining of cast or wrought bulk material. Differently from this subtractive fabrication, in additive manufacturing process, components are produced directly from metal powder in layer-by-layer manner. To date, the most established additive manufacturing technique for fabrication of metallic components include (i) laser engineered net shaping-LENS,

L. P. M. Santos;

E-mail address: santos.lpm87@gmail.com (ii) electron beam melting-EBM and (iii) direct metal laser sintering-DMLS. In the DMLS process, laser fuses metal powder to form the desired part which is defined by a CAD model. A description of the technique can be found in ref. [1].

In comparison to the cast or forged alloys, parts produced by DMLS technique have different microstructural features which are not fully understood to date [2,3]. Thus, there is a need to evaluate influence of process parameters and postmanufacturing treatment on resulting microstructure and materials properties. In the work present, development of the microstructure in the $\alpha+\beta$ Ti-6Al-4V alloy produced by the DMLS process and post-manufacturing treatment is investigated. Series of heat treatments were performed to investigate response of the material.

\section{EXPERIMETAL PROCEDURE}

\section{A. Material}

DMSL Eosint EOS 270 equipment was used to produce exploratory samples $\left(10 \times 10 \times 10 \mathrm{~mm}^{3}\right)$ under argon atmosphere with gas atomized Ti-6Al-4V powder (EOS Titanium Ti64 powder for EOSINT M 270 Systems). Parallel and cross laser beam scanning strategy was employed with following parameters: hatch spacing $100 \mu \mathrm{m}$, layer thickness $30 \mu \mathrm{m}$, laser power $170 \mathrm{~W}$ and scanning speed $1250 \mathrm{~mm} / \mathrm{s}$. Nominal chemical composition of metal powder is shown in Table 1 .

Table 1 - Nominal chemical composition of metal powder.

\begin{tabular}{ccccccccc}
\hline Element & $\mathrm{Al}$ & $\mathrm{V}$ & $\mathrm{O}^{*}$ & $\mathrm{~N}^{*}$ & $\mathrm{C}^{*}$ & $\mathrm{H}^{*}$ & $\mathrm{Fe}^{*}$ & $\mathrm{Ti}$ \\
\hline \multirow{2}{*}{$\mathrm{wt} \%$} & $5.5-$ & $3.5-$ & $<2000$ & $<500$ & $<800$ & $<120$ & $<2500$ & bal \\
& 6.5 & 4.5 & & & & & & \\
\hline
\end{tabular}

* ppm 


\section{B. Heat treatment and microstructural investigation}

Samples were annealed for $1 \mathrm{~h}$ above $\beta$ phase transus temperature at $1040^{\circ} \mathrm{C}$ with subsequent cooling in furnace and in water. The heat treatments were conducted in an electricresistant furnace in ambient atmosphere. Four conditions were studied, as shown in Table 2. Metallographic specimens were prepared by grinding with $\mathrm{SiC}$ paper up to 1200 mesh followed by polishing with alumina of 1 and $0.5 \mu \mathrm{m}$. Samples were then etched in solution of $5 \mathrm{~mL} \mathrm{HNO}_{3}, 3 \mathrm{~mL} \mathrm{HF}$ and $100 \mathrm{~mL} \mathrm{H}_{2} \mathrm{O}$. Microstructural investigation was carried out using Olympus ${ }^{\circledR}$ BX-51M optical microscope and Philips ${ }^{\circledR}$ LX-30 scanning electron microscope.

Vickers microhardness (HV0.5) measurements were conducted using $0.5 \mathrm{~kg}$ work load. An average value of the discrete readings from at least five measurements was taken as a representative value for the microhardness.

Table 2 - Conditions of Ti-6Al-4V samples

\begin{tabular}{ccccc}
\hline Sample & $\begin{array}{c}\text { Scanning } \\
\text { strategy }\end{array}$ & $\begin{array}{c}\text { Heat } \\
\text { treatment }\end{array}$ & Condition & HV0.5 \\
\hline I & $\begin{array}{c}\text { Parallel } \\
\text { beam }\end{array}$ & - & As received & $353 \pm 3$ \\
II & $\begin{array}{c}\text { Cross } \\
\text { beam }\end{array}$ & - & As received & $351 \pm 2$ \\
& $\begin{array}{c}\text { Cross } \\
\text { beam }\end{array}$ & $1040^{\circ} \mathrm{C} / 1 \mathrm{~h}$ & $\begin{array}{c}\text { Cooling in } \\
\text { water }\end{array}$ & $394 \pm 6$ \\
III & $\begin{array}{c}\text { Cooling in } \\
\text { furnace }\end{array}$ & $300 \pm 21$ \\
IV & $\begin{array}{l}\text { Cross } \\
\text { beam }\end{array}$ & $1040^{\circ} \mathrm{C} / 1 \mathrm{~h}$ & \begin{tabular}{c} 
Cun \\
\hline
\end{tabular}
\end{tabular}

\section{X-ray diffraction (XRD)}

XRD measurements were performed on grinded ( $\mathrm{SiC}$ paper 400 mesh) faces perpendicular to the deposition direction using a Philips ${ }^{\circledR} \mathrm{X}^{\prime}$ Pert Pro diffractometer in step scan mode with step size $0.013^{\circ}$, time per step 200s and angular interval $30-90^{\circ}$. $\mathrm{CuK} \alpha(0.1540 \mathrm{~nm})$ radiation with monochromator was used at $40 \mathrm{kV}$ and $45 \mathrm{~mA}$. Spinner was employed to minimize the texture effect. Semi-quantitative analyses and phase identification were done using the X'Pert HighScore ${ }^{\circledR}$ software. XRD patterns were compared with files from ICSD database.

\section{RESUlTS AND DISCUSSION}

\section{A. Microstructural observation}

Figure 1(a-b) shows three-dimensional image montage of microstructure of as received samples fabricated by (a) parallel and (b) cross scanning strategy. A checkered structure $95 \times 95 \mu \mathrm{m}$ in the top view was observed, contoured with white phase. Columnar prior $\beta$ grains $\sim 2 \mathrm{~mm}$ in length are visible in the front and the lateral view. The width of these grains is approximately $95 \mu \mathrm{m}$ which corresponds to the hatch spacing used in the process $(100 \mu \mathrm{m})$.

The microstructure of sample heat treated at $1040^{\circ} \mathrm{C}$ for $1 \mathrm{~h}$ with subsequent cooling in furnace showed $\alpha$ phase contoured by $\beta$ phase as presented in Figure 2(a). In the insert a backscattered electron image of the microstructure in the same sample is shown with $\alpha$ phase (dark) and $\beta$ phase (bright). A heat treated sample at $1040^{\circ} \mathrm{C}$ for $1 \mathrm{~h}$ followed by cooling in water is shown in Figure 2(b). Due to the higher cooling rate, a refined martensitic laths structure within polygonal grains is formed. These results are in good agreement with studies conducted by Warwick et al., [4], Lütjering [5] and SallicaLeva et al., [6].

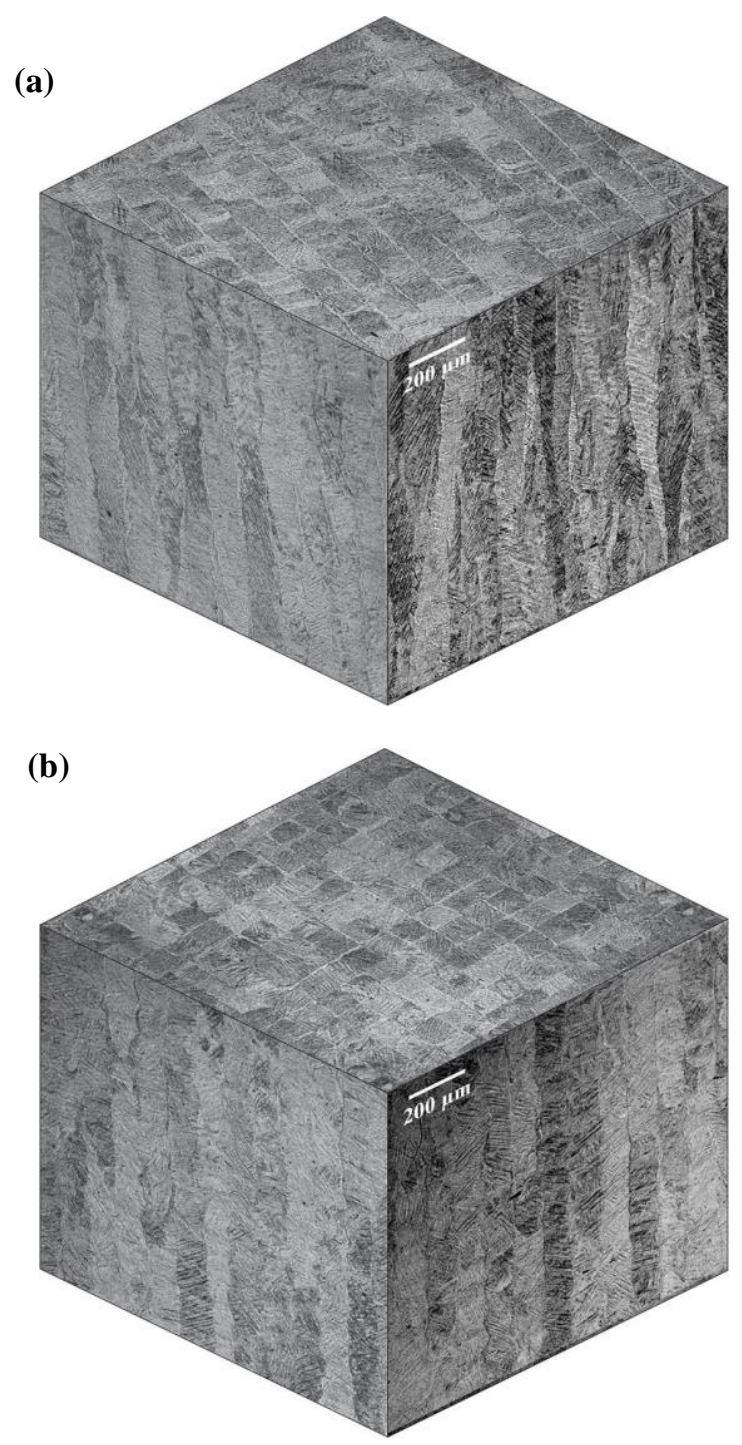

Figure 1 - 3D montage optical micrographs of as received Ti6Al-4V samples fabricated by the DMLS technique employing (a) parallel and (b) cross scanning strategy. 

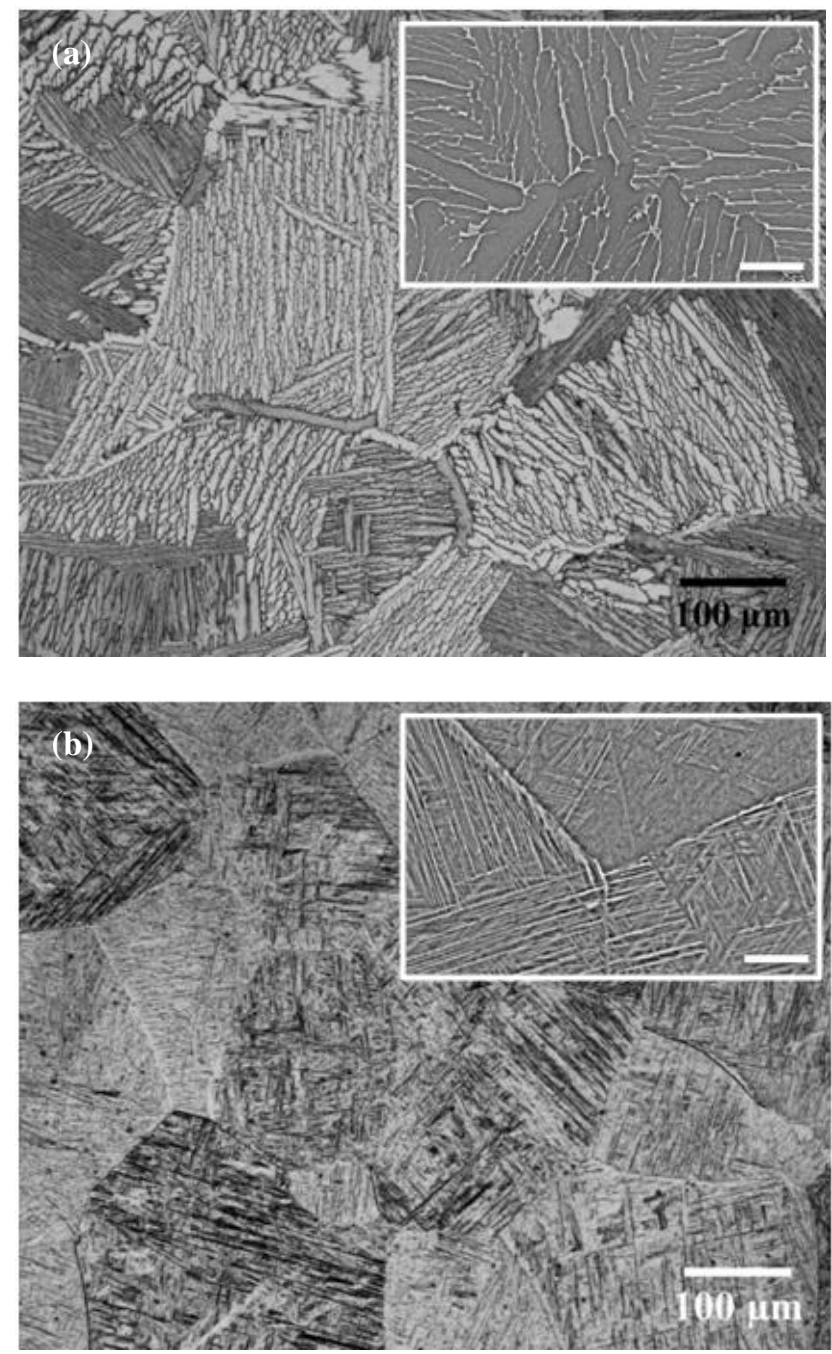

Figure 2 - Optical micrographs of heat treated Ti-6Al-4V samples at $1040^{\circ} \mathrm{C}$ for $1 \mathrm{~h}$ followed by (a) furnace and (b) water cooling. In the inset a backscattered electron micrograph of the same sample is shown. The scale bar in the inset is $20 \mu \mathrm{m}$.

\section{B. XRD Analysis}

XRD results from Ti-6Al-4V samples are presented in the Figure 3 . In the as received condition (samples I and II) an hexagonal close packed-hcp titanium $\alpha$ phase (ICSD 43416) was identified from the XRD patterns. No difference was observed between parallel and cross beam laser scanning process. After heat treatment, the XRD patterns revealed that cooling in water (sample III) does not promote formation of $\beta$ phase. In sample cooled in furnace (sample IV) in addition to the hcp $\alpha$ phase presence of body crystal centered-bcc titanium $\beta$ phase (ICSD 76165) was observed. Semi-quantitative analysis indicated a bcc $\beta$ phase volume fraction of about $13 \%$.

\section{Microhardness}

Results of microhardness are shown in Table 2. The highest value was measured in sample heat treated at $1040^{\circ} \mathrm{C}$ for $1 \mathrm{~h}$ followed by water cooling, which can be attributed to the lower grain size and more refined martensitic structure.

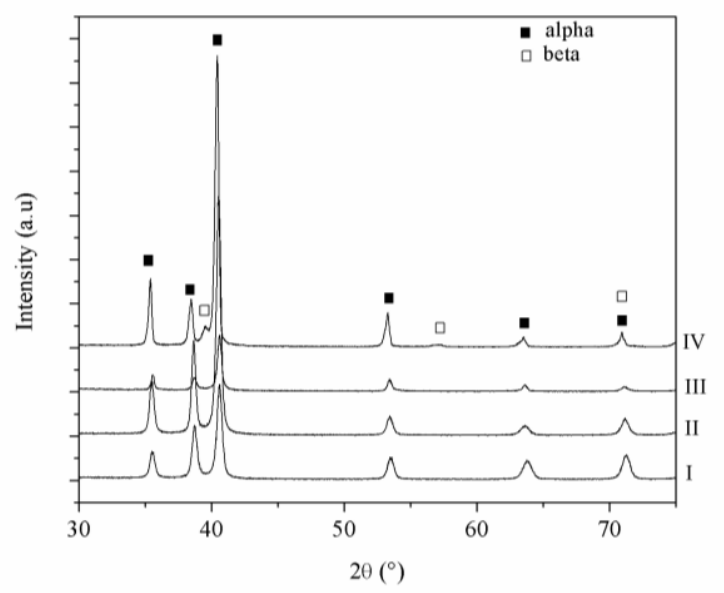

Figure 3 - XRD patterns from DMLS processed Ti-6Al-4V alloy. As received condition parallel beam (I), cross beam (II), heat treated at $1040^{\circ} \mathrm{C}$ for $1 \mathrm{~h}$ and cooled in water (III) and in furnace (IV).

\section{Conclusion}

Ti-6Al-4V alloy was produced by DMLS technique. Based on the results of this investigation, the following conclusions can be drawn:

1. Parallel and cross laser beam strategy does not influence the final microstructure.

2. Slow cooling rate from temperature above $\beta$ transus promotes growth of bcc $\beta$ phase between $\alpha$ laths whereas higher cooling rate results in hcp martensitic structure with high hardness.

\section{ACKNOWLEDGMENT}

The authors would like to acknowledge Ana Claudia de Abreu Siqueira for the help with the XRD measurements.

\section{REFERENCES}

[1] A Simchi, F. Petzoldt, H. Pohl, "On the development of direct metal laser sintering for rapid tooling", J Mater Proces Techn, vol. 141,pp. 319-328, 2003.

[2] L. E. Murr, E. Martinez, K. N. Amato, S. M. Gaytan, J. Hernandez, D. A. Ramirez, P. W. Shindo, F. Medina, R. B. Wick, "Fabrication of Metal and Alloy Components by Additive Manufacturing: Examples of 3D Materials Science", J Mater Res Techn, vol. 1, pp. 42-54, 2012.

[3] L. E. Murr, S. A. Quinones, S. M. Gaytan, M. I. Lopez, A. Rodela, E. Y. Martinez, D. H. Hernandez, E. Martinez, F. Medina, R. B. Wicker, "Microstructure and mechanical behavior of Ti-6Al-4V produced by rapid-layer manufacturing, for biomedical applications", $J$ Mech Behavior Bio Mater, vol. 2, pp. 20-32, 2010.

[4] J.L.W. Warwick, N.G. Jones, I. Bantounas, M. Preuss, D. Dye, "In situ observation of texture and microstructure evolution during rolling and globularization of Ti-6Al-4V", Acta Mater, vol. 61, pp. 1603-1615, 2013.

[5] G. Lütjering, "Influence of processing on microstructure and mechanical properties of $(\alpha+\beta)$ titanium alloys", Mater Sci Eng A, vol. 243A, pp. 3245, 1998.

[6] E. Sallica-Leva, A.L. Jardini, J.B. Fogagnolo, "Microstructure and mechanical behavior of porous Ti-6Al-4V parts obtained by selective laser melting", J Mech Behavior Bio Mater, vol. 26, pp. 98-108, 2013. 